二軸エクストルーダー炕理による ヘミセルロースのアルカリ抽出

$$
\text { 山口文秀* ・清水典子* ・ 川田正美* }
$$
高木義和 ${ }^{*} \cdot$ 前田 進 ${ }^{*}$

Extraction of Hemicellulose in Alkaline Condition using Twin Screw Extruder

Fumihide Yamaguch " , Noriko Shimizu*, Masami KaWAdA ", Yoshikazu TaKagI" and Susumu MAEDA*

"Japan Tabacco Inc., Food R\&D Center, 6-2, Umegaoka, Midori-ku, Yokohama, Kanagawa 227

Extraction of hemicellulose from corn bran under alkaline conditions using a twin screw extruder was examined. Extruding pressure was adjusted by a volume of $\mathrm{NaOH}$ solution added to the corn bran. Samples were supplied into the extruder by gravity feed. The pressure increased from 1 to 16 $\mathrm{kg} / \mathrm{cm}^{2}$ with decreasing water content in corn bran. In the case that the amount of $\mathrm{NaOH}$ was fixed, extraction rates of hemicellulose did not increase against increasing pressure. The best extraction rate was attained when 0.5 or $1.0 \mathrm{~N} \mathrm{NaOH}$ was added at $2 \sim 2.5$ times weights of corn bran. These results suggest that mixing and dispersion effects with viscosity fall inner the twin screw extruder are more important factors for extraction of hemicellulose than high pressure.

(Received Oct. 23, 1991)

穀物外皮に含まれている水溶性へミセルロースは植物 細胞の細胞壁を構成する成分であるが，その血清コレス テロール上昇抑制効果がすでに確認されていること党2， 水溶性であるので飲料などへの利用が可能であることな どから注目を集めている．このへミセルロースは本来水 溶性のものであるが，細胞壁の状態では不溶性のセルロ ースミクロフィフリルと水素結合しているため容易には
抽出できず，アルカリ，加熱，加圧などの負荷を加える ことによって初めて抽出が可能になる゙．

一方、エクストルーダーは短時間高温加熱に加え，混 合，混練，㥍断，破砕，加圧，成形，膨化，乾燥，殺菌 の多くの操作を 1 台で行なえる多目的の食品加工機械で ある(1)57.このエクストルーダーを用いてへミセルロー スを抽出する試みとしてはいくらかの特許があるが，中 性で加圧装置として用いたものが主であった ${ }^{67)}$. 最近 では，アルカリ存在下での反応装置として用いた例もあ るが ${ }^{8)}$ この際の抽出条件は検討されておらずエクスト ルーダーの持つどの特性が効いたかは明らかではない， そこで本報では，代表的な穀物外皮であるコーンブラン を材料に用い，アルカリ存在下での二軸型エクストルー ダーの使用が，穀物外皮加らのへミセルロースの抽出に 有効であるのかにっいて検討した.

\section{1. 実験材料および方法}

\section{(1) 実験材料}

コーンブランは，A.E. STRLEY Mfg. Co. のベス トブラン 90 を使用した、べストブラン 90 には食物絆維 が $92 \%$ ，へミセルロースが $67 \%$ 含まれている.

(2) エクストルーダー

エクストルーダーは日本製鋼所製の小型二軸エクスト ルーダー model TEX-L (ラボルーダー) 用いて, Fig. 1 に示したスクリューパターンで行なった。 スク リューの直径が $30 \mathrm{~mm}$, 長さが $300 \mathrm{~mm}(L / D=10)$, ダイの直径が $4 \mathrm{~mm}$ (一穴)のものを用い，回転数は $80 \mathrm{rpm}$ ，バレル先端温度を $110^{\circ} \mathrm{C}$ に設定した。試料の 供給は自然供給で行ない，ダイから放出される試料の量 を測定することにより処理速度を算出した，その際の処

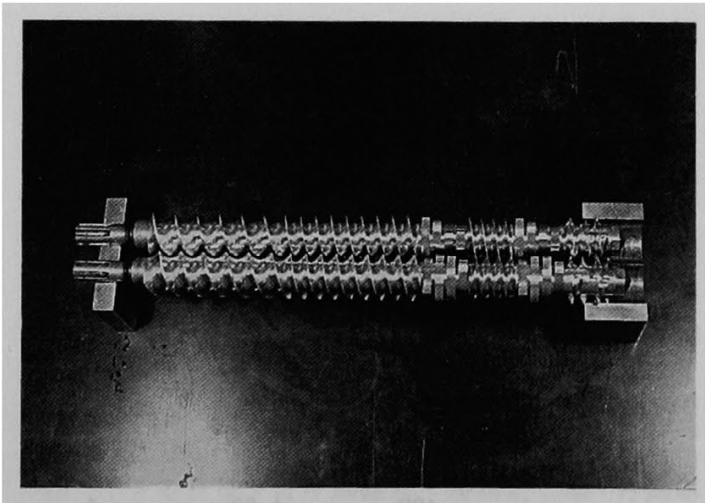

Fig. 1 Screw parts used for extraction of hemicellulose

*日本たばこ産業株式会社食生活研究所（テ227 横浜市緑区梅ヶ丘 6 番 2) 
理速度，先端压力を Table 1 に示した。

(3) ヘミセルロースの抽出方法

$200 \mathrm{~g}$ の試料と一定量の $\mathrm{NaOH}$ 溶液（Table 1) を 十分混合後，上記の条件で二軸エクストルーダーで処理 しへミセルロースを抽出した. 次に, $\mathrm{NaOH}$ 添加前の 試料重量 $10 \mathrm{~g}$ 相当分のエクストルーダー処理物に蒸留 水を $200 \mathrm{~m} l$ に達するまで加水し，1 時間室温で擋䢁す ることによって抽出されたへミセルロースを溶出させた. $6000 \mathrm{rpm}, 20$ 分間の遠心分離により溶出残査を除去し, 得られた画分を抽出画分上した。

（4）水溶性高分子成分の定量

抽出画分中の水溶性高分子成分の定量はゲルろ過カラ ムを用いた HPLC 分析により行なった．まず，得られ た抽出画分 $10 \mu l$ を下記のシステムで HPLC 分析を行 ない，その Void volume から Retention time 20 分 までの高分子画分のエリア面積を計算した．次に，水溶 性高分子画分のエリア面積と，キシロースを標準物質と したフェノール硫酸法")により定量した水溶性高分子画 分の全糖量の補正值をもとにして全糖量に換算し，それ

Table 1 Process conditions during extrusion treatment of corn bran

\begin{tabular}{|c|c|c|c|}
\hline $\begin{array}{l}\mathrm{NaOH} \\
\text { concentration }\end{array}$ & Volume $^{\text {a) }}$ & $\begin{array}{l}\text { Process } \\
\text { rate } \\
(\mathrm{kg} / \mathrm{h})\end{array}$ & $\begin{array}{l}\text { Maximum } \\
\text { pressure } \\
\left(\mathrm{kg} / \mathrm{cm}^{2}\right)\end{array}$ \\
\hline \multirow{4}{*}{$0.5 \mathrm{~N}$} & 200 & 7. 22 & 16 \\
\hline & 300 & 4. 13 & 3 \\
\hline & 400 & 2. 33 & 2 \\
\hline & 500 & 5. 16 & 1 \\
\hline \multirow{4}{*}{$1.0 \mathrm{~N}$} & 200 & 6. 31 & 16 \\
\hline & 300 & 5. 76 & 7 \\
\hline & 400 & 3. 29 & 3 \\
\hline & 500 & 2. 35 & 2 \\
\hline \multirow{3}{*}{$2.0 \mathrm{~N}$} & 200 & 6.47 & 8 \\
\hline & 300 & 4. 73 & 3 \\
\hline & 400 & 4. 04 & 2 \\
\hline \multirow{5}{*}{$4.0 \mathrm{~N}$} & 500 & 3. 33 & 1 \\
\hline & 200 & 6. 34 & 6 \\
\hline & 300 & 5. 51 & 2 \\
\hline & 400 & 4. 69 & 1 \\
\hline & 500 & 5. 18 & 1 \\
\hline
\end{tabular}

a) Volume of $\mathrm{NaOH}$ solution added to $200 \mathrm{~g}$ of rerified corn bran.
を水溶性高分子成分量とした。

なお，使用した HPLC 分析条件は以下の通りで行な った。装固 : 島津 LC-9 A システム, カラム : TSKgel G $5000 \mathrm{PW}(7.5 \mathrm{~mm} \mathrm{ID} \times 60.0 \mathrm{~cm}$, Toso $)$, カラ 么温度: $50^{\circ} \mathrm{C}$, 流速: $1.0 \mathrm{ml} / \mathrm{min}$, 移動相: $0.05 \mathrm{M}$

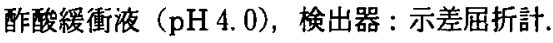

（5）構成糖（中性糖）の分析

抽出画分中の構成糖（中性糖）の分析は $2 \mathrm{~N}$ 硫酸中 で 2 時間惹沸後 ${ }^{10)}$, 脱塩し，以下のシステムの HPLC 分析により分析した。. 装置: 島津 LC-6 A システム、 カラム: Aminex HPX-87 P $(7.8 \mathrm{~mm} \mathrm{ID} \times 30.0 \mathrm{~cm}$, Bio-rad), カラム温度: $85^{\circ} \mathrm{C}$, 流速: $0.6 \mathrm{ml} / \mathrm{min}$, 移動相: 蒸留水, 検出器: 示差届折計.

\section{2. 実験結果および考察}

コーンブランを用い，アルカリ存在下での二軸エクス トルーダーによるへミセルロース抽出条件を検討した. 方法としては，まずコーンブラン $200 \mathrm{~g} に 0.5,1.0$, $2.0,4.0 \mathrm{~N}$ の各規定数の $\mathrm{NaOH}$ 溶液を 200,300 , $400,500 \mathrm{ml}$ ずつ添加し，エクストルーダー処理を行な った．次に，この処理物に蒸留水を加え 1 時間擋捧し抽 出された可溶性成分を溶出させ HPLC 法で分析した.

エクストルーダー処理は，バレル先端温度を穀物へミ セルロースのアルカリ抽出において高收率を示す $110^{\circ} \mathrm{C}$ に固定し，試料の供給は自然供給とした．その際の試料 の処理速度，スクリュー先端部の圧力を湘定した結果を Table 1 に示す. 処理速度に開きがあるが, $\mathrm{NaOH} の$ 添加量を増加するにつれて圧力が咸少する傾向にあるこ とが分かる。また， $\mathrm{NaOH}$ 溶液の添加量を $500 \mathrm{ml}$ よ り増加させるとバレル内で液相と固相の分離が起こり不 連続な処理となった。一方, $200 \mathrm{~m} l$ より少ない場合に は駆動系に対する負荷がかかりすぎるために本装置では 処理できなかった。

次に，処理後の試料に加水，室温で擋拌することによ り抽出された成分を溶出させた。 その抽出画分の水溶性 高分子成分をゲルろ過による HPLC を用いて分析した ところ平均分子量 100 万の高分子の溶出を確認した。 そ の高分子成分量をフェノール硫酸法により定量した結果 を Fig. 2 に示す. 横軸にはエクストルーダー好理時に コーンブラン $200 \mathrm{~g}$ に対して加えた $\mathrm{NaOH}$ 溶液の量を， 縦軸にはコーンブラン全体に対する水溶性高分子画分の 回収率を示した．2.0，4.0 N の $\mathrm{NaOH}$ の液量を 400 $\mathrm{m} l$ から $500 \mathrm{~m} l$ と増加させた時には水溶性画分の回収 率が横ばい，おるいは隇少したが，それ以外のところで は $\mathrm{NaOH}$ 溶液の液量が増加するにつれて，水溶性成分 


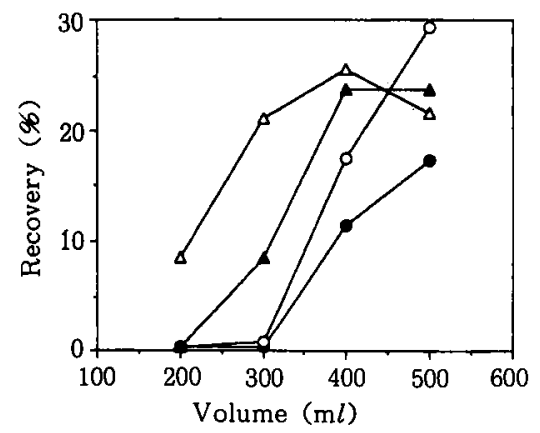

Fig. 2 Effects of volume and concentration of $\mathrm{NaOH}$ solution added to $200 \mathrm{~g}$ of purified corn bran on recovery of hemicellulose

- : $0.5 \mathrm{~N} \mathrm{NaOH}, O: 1.0 \mathrm{~N} \mathrm{NaOH}, \triangle: 2.0 \mathrm{~N}$ $\mathrm{NaOH}, \triangle: 4.0 \mathrm{~N} \mathrm{NaOH}$

の回収率も増加した。また， $4.0 \mathrm{~N} \mathrm{NaOH} 200 \mathrm{ml}$ と 2. $0 \mathrm{~N} \mathrm{NaOH} 400 \mathrm{~m} l$, あるいは $2.0 \mathrm{~N} \mathrm{NaOH} 200 \mathrm{~m} l$ と1.0 N NaOH $400 \mathrm{ml}$ のように NaOH の絶対量が同 じ場合です $\mathrm{NaOH}$ の湤量が多い方が回収率が高かった。

次に，各抽出画分の中性糖含量を測定した，各画分加 らはキシロースとアラビノース，および少量のガラクト ース，グルコースが検出された．このキシロース，了ラ ビノースの含量の增減と，Fig. 2 のゲルろ過での高分 子成分の回収率の閒には高い相関関係があり，本報で定 量した高分子成分はキシロース，アラビノースが主成分 であるへミセルロースであることが示咬された。この実 験で抽出されたへミセルロースは，分子量が 100 万程度， アラビノース/キシロース比が 0.52 であり，この值は竹 内らがとうもろこしから $2.0 \% \mathrm{NaOH}$ で抽出したコー ンブランヘミセルロース（CBH）とほぼ一致した。

当初, 二軸エクストルーダーの加圧効果が抽出率の向 上に関与するのではないかと考え実験を行なったが，今 回の実験では加圧はあまり抽出率の向上には関与廿ず， むしろアルカリの添加量が多い方が抽出率が向上してい た (Table 1, Fig. 2).この結果は, 材料へのアルカ リ添加量を增やすことによる粘度の低下が，二軸エクス トルーダー内での材料の流動性や分散性を向上させ，了 ルカリを効率的に利用できた結果ではないかと推測でき る.この説が正しいと仮定すると，スクリニ一回転数を 上げるなどの装置内での混合分散効果を上げる操作を行 なうことによって，さらに抽出効率が上がる事が期待で きる。
本報で示した方法は，材料に対して2 2.5 倍程度の アルカリ溶液の量で斎むことや，2２.5 N のアルカリ 溶液を用いるのはエクストルーター処理時の短時間のみ で, へミセルロースの溶出時から後の工程は 0.1〜 $0.125 \mathrm{~N}$ の希アルカリ溶液として処理できるなどの利点 を持っている，抽出温度，スクリュ一回転数などェクス トルーダーによる抽出条件，加水による溶出の条件，装 置のアルカリに対する耐久性などを更に検討する必要が あるが，以上の結果より二軸エクストルーダーを，アル カリ抽出のリアクターとして用いることによって，款物 外皮からへミセルロースを効率的に抽出できることが示 された。

\section{3. 要 約}

ヘミセルロースの効率的抽出を目的として，二軸エク ストルーターを使用し，加圧下でアルカリによるへミセ ルロースの抽出を、コーンフランを材料として検討した． 内部圧力の調整は，自然供給の状態で，試料に対し加水 量を変化させることにより行なった。

コーンブランの場合，加水量を滅らすことにより圧力 は 1 から $16 \mathrm{~kg} / \mathrm{cm}^{2}$ まで上昇したが、了ルカリの絶対 使用量が同じであれば，圧力が増加してあへミセルロー スの抽出の向上は認められなかった. $0.5 \mathrm{~N}, 1.0 \mathrm{~N}$ の $\mathrm{NaOH}$ の試料の 2 加 2.5 倍加えた場合に, 1 加ら 3 $\mathrm{kg} / \mathrm{cm}^{2}$ の加圧下で最もよい効率で抽出できたことから， 高圧処理よりむしろ二軸エクストルーダー内部での粘度 低下に伴う混合分散勃果が抽出率の向上に寄与すること が示唆された。

\section{文献}

1）綾野雄幸・太田富貴雄・渡辺幸雄・中村 強・滝 沢まゆみ：栄養と食糧，35，431（1982）。

2）竹内政保・菅原正義・高庄敏幸・江頭祐嘉合・真 田宏夫・綾野婎幸：日食工誌，38，981（1991）。

3）小林幹彦: 多糖の分離・精製法: 初版 (学会出版 センター，東京)，p. 19，(1987）。

4）土井悦四郎：食品工業における化学，技術の進歩 （II），第 1 版（光琳・東京），p. 81，(1986).

5）野口明徳・五十部諴一郎：日食工誌，33，798 (1986)

6) Tyson, G.J. and Madison, W.: USP 4842877 .

7）小笠原武雄・佐々木康人・窪田正二郎・片岡軍 司 : 特開平 2-124069.

8）青江誠一郎・小田泰士・中岡正令・黑沢誠治：特 開平 2-276801.

9) Dubois, M., Gilles, K.A., Hamilton, J.K., 
Rebers, P.A. and Smith, F. : Anal. Chem., 28, 350 (1956).

10) Hough, L., Jones, J.V.S. and Wusteman,
P. : Carbohydr. Res., 21, 9 (1972).

(平成 3 年 10 月 23 日受理) 